\title{
Effect of Cobalt Ion on the Enzymatic Activity of Pseudomonas aeruginosa Alkaline Proteinase
}

\author{
Kazuyuki Morihara and Hiroshige Tsuzuki \\ Shionogi Research Laboratory, Shionogi and Co., Ltd., Fukushima-ku, Osaka 553 \\ Received October 11, 1973
}

\begin{abstract}
Pseudomonas aeruginosa alkaline proteinase was inactivated by o-phenanthroline in the presence of high concentration of $\mathrm{Ca}$ ion, which suggested that the enzymatic activity is related not to $\mathrm{Ca}$ ion but to another heavy metal ion. Among various metal ions tested, Co ion was effective in promoting hydrolysis, a several-fold increase in hydrolysis being observed in the presence of $\mathrm{Co}$ at a concentration higher than $5 \times 10^{-3} \mathrm{M}$. A kinetic study indicated that the promotion related mainly with binding $(\mathrm{Km})$ and little with catalysis $\left(k_{\mathrm{cat}}\right)$. The points of cleavage in oxidized insulin B chain were assumed to be identical in the presence or absence of Co ion.
\end{abstract}

Pseudomonas aeruginosa produces two proteinases which are separable by columnchromatography on DEAE-cellulose. ${ }^{1 \prime}$ Both the enzymes have been crystallized and their physico-chemical and enzymatic properties clarified. ${ }^{2 \sim 6}$ ) One of the enzymes is most active in neutral $\mathrm{pH}$ range, and as it is active on elastin it can be called an "elastase". ${ }^{6}$. The elastase is a typical metal-chelator sensitive neutral proteinase ${ }^{7,8)}$ which shows specificity against bulky or hydrophobic amino acid residues at the imino-side of the splitting point.

The other enzyme is most active at slightly alkaline $\mathrm{pHs}^{21}$ but does not hydrolyze elastin, ${ }^{9 \prime}$ and it might therefore be called an "alkaline proteinase." This enzyme is inactivated by various metal-chelators but not by DFP,* PCMB, etc.," ${ }^{2,4}$ similarly as seen with the "elastase". ${ }^{\theta)}$ Nevertheless, the specificity of the alkaline proteinase against oxidized insulin B chain was completely different from that of the "elastase" 7) A study using various synthetic peptide substrates has shown ${ }^{10)}$ that

* Abbreviations used are: DFP, disopropyl phosphofluoridate; PCMB, p-chloromercuribenzoic acid; EDTA, ethylenediamine tetra-acetate. Abbreviated designations of peptides or their derivatives obey the tentative rules of the IUPAC-IUB Commission of Biochemical Nomenclature. Except where specified, the constituent amino acids were all of the b-configuration. the specificity of the alkaline proteinase is determined rather by the amino acid residues distant from the splitting point (e.g., "secondary interaction") than by those on either side of the splitting point (e.g., "primary specificity") in an oligopeptide substrate.

The metal content of the "elastase" has not been determined, but like the other neutral proteinases from bacterial origin, ${ }^{11,12}$ it may be a Zn-enzyme. The alkaline proteinase does not contain a significant amount of any metal ion except $\mathrm{Ca}$ (one to two gramatoms of $\mathrm{Ca}$ per mole of enzyme). ${ }^{4}$ The question then arises whether the inactivation of the alkaline proteinase by metal-chelators occurs by a mechanism similar to that observed with usual neutral proteinases from bacterial origin. The present study was undertaken to investigate whether the constituent $\mathrm{Ca}$ ion is essential for activity of the alkaline proteinase, and whether any other metal ion is essential for its activity.

\section{MATERIALS AND METHODS}

Enzyme. The crystalline proteinase of $P$. aeruginosa IFO 3080 (twice recrystallized) was prepared according to the method described previously. ${ }^{2)}$ The preparation was found to be homogeneous in discelectrophoresis at $\mathrm{pH} 8$.

Substrates. Z-Phe-Ala-Ala, Z-Ala-Gly-Gly-Leu, and Z-Ala-Phe-Gly-Ala were synthesized according to 
the methods given in the previous papers. ${ }^{10,13)}$ Zinc insulin (crystals) was kindly donated by Lilly Laboratories, Indianapolis, Indiana. Oxidized B-chain was prepared according to the method of Hayashi, ${ }^{14)}$ which is a modification of the method of Sanger. ${ }^{15}$

Hydrolysis of synthetic peptides. A reaction mixture $(1 \mathrm{ml})$ containing $0.05 \mathrm{M}$ Tris-buffer of pH 7.0, an appropriate concentration of peptide, and a suitable amount of enzyme was incubated at $40^{\circ} \mathrm{C}$. At three minute intervals $0.1 \mathrm{ml}$ of the reaction mixture was transferred into a test tube containing $1 \mathrm{ml}$ of a mixture of $0.5 \mathrm{M}$ citrate buffer ( $\mathrm{pH}$ ) and $0.01 \mathrm{M}$ EDTA solution to stop further hydrolysis. The extent of hydrolysis was measured by the ninhydrin method of Yemm and Cocking. ${ }^{16}$ )

The sites of action of enzyme upon substrates were determined by paper chromatography of the hydrolyzates in comparison with authentic compounds, or by paper-electrophoresis in a current of $1200 \mathrm{~V}$ at $\mathrm{pH} 2$ ( $0.6 \mathrm{M}$ formic acid and $2 \mathrm{M}$ acetic acid, $1: 1$, by volume) for $50 \mathrm{~min}$. The results indicated that Z-Phe-Ala-Ala, Z-Ala-Gly-Gly-Leu, and Z-Ala-Phe-Gly-Ala were split by the enzyme at the peptide bonds shown by the arrows.

The color yields by the ninhydrin method of Ala-Ala, Gly-Leu, and Gly-Ala, based on L-leucine as $100 \%$, were given in previous papers. ${ }^{13,17}$ The initial velocity for each peptide was calculated using the corresponding standard curve.

Gelatin-hydrolysis. The activity was measured according to the method of Ottesen and Spector ${ }^{18)}$ using the $\mathrm{pH}$-stat technique at $\mathrm{pH} 8.0$ and $30^{\circ} \mathrm{C}$ with $10 \mathrm{ml}$ of $0.5 \%$ gelatin solution as substrate and $0.05 \mathrm{~N} \mathrm{NaOH}$ as titrant. Activities were estimated from initial rates and expressed as $\mu$ eqv. $\mathrm{H}^{+} / \mathrm{min} / \mathrm{mg}$ enzyme/ml.

Kinetic study. In all cases, satisfactory MichaelisMenten kinetics were observed, and plots of $1 / \mathrm{V}$ vs $1 / \mathrm{S}$ (Lineweaver-Burk plots) permitted the fitting of definite straight Iines. For each determination of $K m$ and $V_{\max }$ derived from such plots, initial rates were measured from five (or more) values of the initial substrate concentration S. Depending upon the rate of enzymatic cleavage, the enzyme concentration was suitably adjusted; it was assumed that the molecular weight was $48,400{ }^{3}$ This enzyme concentration was used to calculate $k_{\mathrm{cat}}$ from $\mathrm{V}_{\max }$ values.

Determination of the points of cleavage in oxidized insulin $B$ chain. The digestion of oxidized insulin B chain $([\mathrm{S}]=4 \mathrm{mg} / \mathrm{ml} ; \mathrm{E}: \mathrm{S}=1: 100, \mathrm{w} / \mathrm{w}$ ) was carried out at $25^{\circ} \mathrm{C}$ in the presence of $0.1 \mathrm{M} \mathrm{KCl}$ and $0.01 \mathrm{M}$ $\mathrm{CoCl}_{2}$. The $\mathrm{pH}$ of the reaction mixture was kept at 7.5 by the aid of a Radiometer pH-stat. After $20 \mathrm{hr}$ reaction, the digest was frozen and lyophilized. Separation of peptides was performed by high voltage paper- electrophoresis at pH 3.7 (pyridine, acetic acid, and water, 1:10:280, v/v) for $90 \mathrm{~min}$ at $2000 \mathrm{~V}$. The peptides separated were detected by spraying ninhydrin solution onto guide strips, and eluted with $30 \%$ acetic acid. The eluates are designated by Roman numerals in order from right ("positive" charge) to left ("negative" charge) in the paper-electrophoresis.

After evaporation in vacuo, each peptide fraction was further separated by paper-chromatography (pyridine, n-butanol, acetic acid, and water, 20:30:6:24, v/v). For peptide nomenclature, an alphabetic suffix is added in order from lower to upper positions on the chromatogram. The peptides were eluated with $30 \%$ acetic acid, then dried and hydrolysed with $0.5 \mathrm{ml}$ of twice distilled $6 \mathrm{~N} \mathrm{HCl}$ for $24 \mathrm{hr}$ at $105 \pm 1^{\circ} \mathrm{C}$ in sealed and evacuated tubes. The hydrolyzates were dried in a rotary evaporator and the amino acid compositions were determined by an amino acid analyzer (Hitachi KLA-Type 2) for determination of the points of cleavage in oxidized insulin B chain.

\section{RESULTS}

\section{Effect of o-phenanthroline in the presence of Ca ion}

It is well-known ${ }^{19}$, that $o$-phenanthroline binds Ca very weakly $\left(\log K_{1}=0.7\right)$ while binding strongly heavy metal ions such as $\mathrm{Zn}$ $\left(\log K_{1}=6.36 ; \quad \log K_{2}=5.64 ; \quad \log K_{3}=5.20\right)$. An $o$-phenanthroline-Ca solution should therefore be useful for preferential removal of such heavy metal ions. At a concentration of $2 \times 10^{-3} \mathrm{M} o$-phenanthroline and $10^{-2} \mathrm{M} \mathrm{CaCl}_{2}$ less than one percent of the $\mathrm{Ca}$ ions are complexed. To investigate the role of the $\mathrm{Ca}$ ion constituent of the enzyme molecule, the hydrolysis of Z-Ala-Phe-Gly-Ala was determined in the presence of various concentrations of $o$-phenanthroline and $10^{-2} \mathrm{M} \mathrm{CaCl}_{2}$. The results are summarized in Table I, which indicates that the hydrolysis is inhibited almost completely in presence of $o$-phenanthroline at a concentration higher than $5 \times 10^{-4} \mathrm{M}$, even in the presence of $10^{-2} \mathrm{M}$ of $\mathrm{CaCl}_{2}$. It is therefore clear that the activity of the enzyme is related not to $\mathrm{Ca}$ ion but to other heavy metal ions.

The inhibition was instantaneous under the experimental conditions employed; no greater inhibition was obtained after preincubation with inhibitor than without preincubation. 
Table I. Effect of o-Phenanthroline on the ENZYMatic ACTIVITY of $P$. aeruginosa Alkaline Proteinase

The reaction mixture $(1 \mathrm{ml})$ contained $10 \mathrm{~mm}$ peptide (Z-Ala-Phe-Gly-Ala), $0.02 \mathrm{mg}$ enzyme, $10^{-2} \mathrm{M}$ $\mathrm{CaCl}_{2}$, and $0.05 \mathrm{~m}$ Tris-buffer ( $\mathrm{pH} 7.0$ ). Initial velocities were determined at $40^{\circ} \mathrm{C}$ in the presence of various concentrations of o-phenanthroline shown in the table.

\begin{tabular}{cc}
\hline $\begin{array}{c}o \text {-Phenanthroline } \\
(\mathrm{M})\end{array}$ & $\begin{array}{c}\text { Relative activity } \\
(\%)\end{array}$ \\
\hline 0 & 100 \\
$10^{-5}$ & 74 \\
$2 \times 10^{-5}$ & 70 \\
$5 \times 10^{-5}$ & 44 \\
$10^{-1}$ & 27 \\
$2 \times 10^{-4}$ & 10 \\
$5 \times 10^{-4}$ & 2 \\
$10^{-3}$ & 0 \\
$2 \times 10^{-3}$ & 0 \\
\hline
\end{tabular}

The enzyme inhibition was reversed upon dilution of chelator-enzyme solution or on addition of excess metal ions such as $\mathrm{Zn}, \mathrm{Co}, \mathrm{Mn}$, etc. In a previous paper ${ }^{4}$ it was shown that an EDTA concentration of more than $10^{-2} \mathrm{M}$ was required for inactivation at $\mathrm{pH} 7$, where the remaining activity was determined using casein as substrate. This inconsistency can be explained by considering that the EDTA-inactivated enzyme was reactivated by metal ions contaminating the casein used as substrate, thus necessiating a higher concentration of EDTA for the inactivation.

\section{Effect of Co ion on hydrolysis}

The above suggests that some heavy metal ion is essential for the activity of the enzyme, even though it has been shown ${ }^{4}$ that the enzyme does not contain a significant amount of any metal ion except $\mathrm{Ca}$. The effects of various metal ions on the enzymatic activity were therefore determined using Z-Ala-PheGly-Ala as substrate. The results are summarized in Table II; of the metal ions tested, Co ion alone promoted the rate of hydrolysis. The effect of the concentration of Co ion on hydrolysis was further studied as shown in Table III. A considerable concentration of
Table II. Effect of Various Metal Ions on the EnZYMATIC ACTIVITY of $P$. aeruginosa

Alkaline Proteinase

The reaction mixture $(1 \mathrm{ml})$ contained $10 \mathrm{~mm}$ peptide (Z-Ala-Phe-Gly-Ala), $0.02 \mathrm{mg}$ enzyme, $0.05 \mathrm{M}$ Tris-buffer ( $\mathrm{pH} 7.0)$, and various metal ions $\left(2 \times 10^{-3} \mathrm{M}\right)$ as seen in the table. Initial velocities were determined at $40^{\circ} \mathrm{C}$.

\begin{tabular}{lc}
\hline Metal & $\begin{array}{c}\text { Relative activity } \\
(\%)\end{array}$ \\
\hline Control & 100 \\
$\mathrm{CaCl}_{2}$ & 105 \\
$\mathrm{ZnCl}_{2}$ & 82 \\
$\mathrm{CoCl}_{2}$ & 220 \\
$\mathrm{NiCl}_{2}$ & 100 \\
$\mathrm{MnCl}_{2}$ & 90 \\
\hline
\end{tabular}

Table III. Effect of Concentration of Co lon on the ENZyMatic ACTIVITY of $P$. aeruginosa

\section{Alkaline Proteinase}

Both preincubated and non-preincubated enzyme preparations were used; preincubated enzyme was treated with $\mathrm{CoCl}_{2}$ solution $\left(10^{-2} \mathrm{M}\right)$ for one night at about $4 \mathrm{C}$. The concentrations of $\mathrm{CoCl}_{2}$ in the reaction mixtures are as seen in the table. Other conditions are described in Table II.

\begin{tabular}{ccc}
$\begin{array}{c}\mathrm{CoCl}_{2} \\
(\mathrm{M})\end{array}$ & $\begin{array}{c}\text { Without } \\
\text { pre-incubation } \\
\text { (Relative activity, } \%)\end{array}$ & $\begin{array}{c}\text { With } \\
\text { pre-incubation }\end{array}$ \\
\hline 0 & 100 & - \\
$10^{-5}$ & - & 120 \\
$10^{-4}$ & - & 160 \\
$10^{-3}$ & - & 470 \\
$2 \times 10^{-3}$ & 220 & 630 \\
$5 \times 10^{-3}$ & - & 880 \\
$10^{-2}$ & 430 & 840 \\
$2 \times 10^{-2}$ & 520 & 950 \\
$5 \times 10^{-2}$ & 710 & - \\
\hline
\end{tabular}

Coion $\left(>5 \times 10^{-3} \mathrm{M}\right)$ was required for maximum promotion of hydrolysis, though the requisite concentration differed considerably depending upon whether preincubation with Co ion had been done or not. At the optimum concentration, the rate of hydrolysis was increased several fold. The enzyme activation with Co ion was reversed upon dilution of the activated enzyme. This, together with the above results would indicate that Co ion binds loosely to the enzyme molecule. Similar promotion of hydrolysis by $C o$ ion was observed when other synthetic 

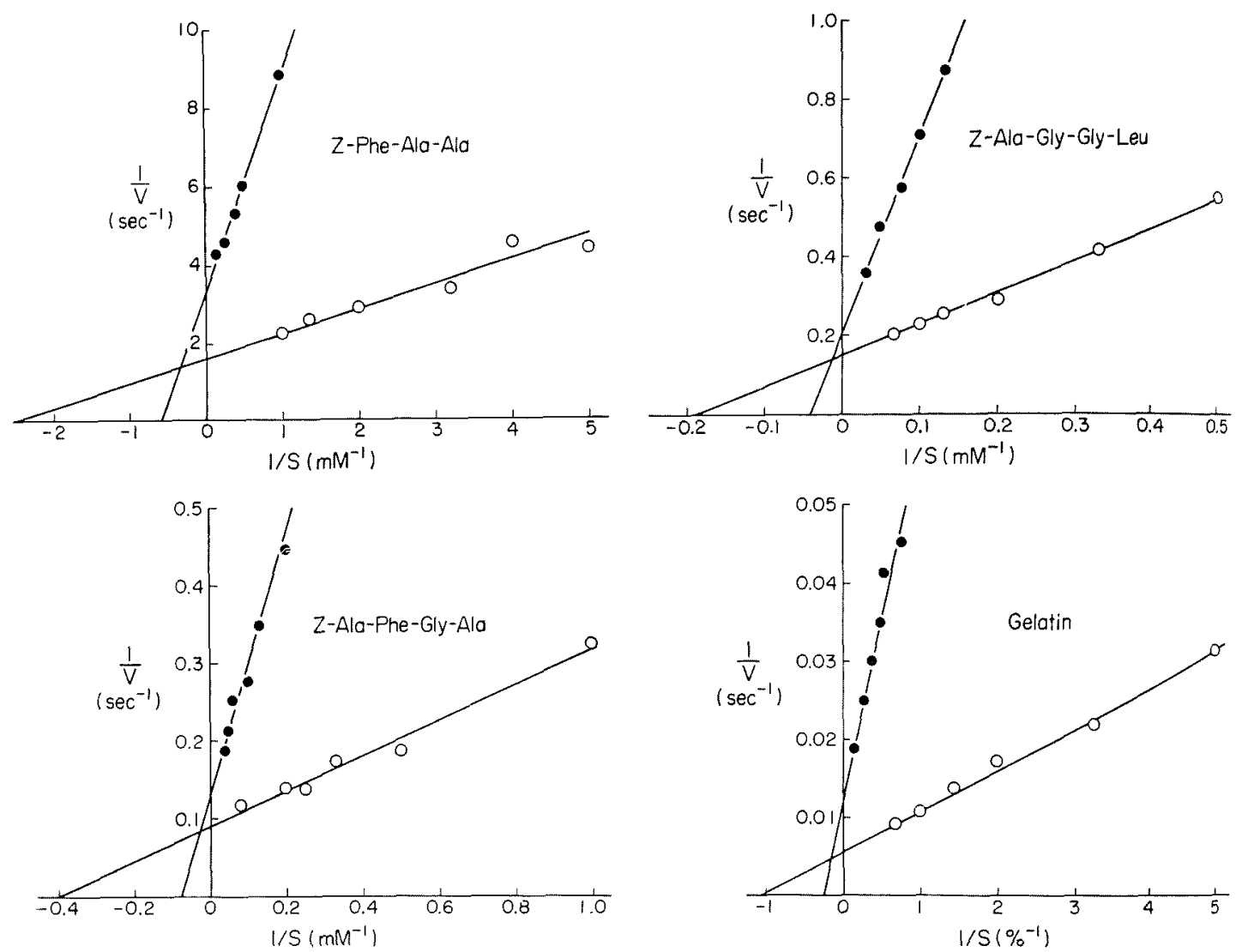

Fig. 1. Lineweaver-Burk Plots of Hydrolysis of Various Peptides and Gelatin by P. aeruginosa Alkaline Proteinase in the Presence or Absence of Co Ion.

The kinetic study was made in the presence $(O)$ or absence $(\bullet)$ of $10^{-2} \mathrm{M} \mathrm{CoCl}_{2}$. The other experimental conditions are described in MATERIALS AND METHODS.

peptides or gelatin were used as substrates.

In order to investigate the role of Co ion in the promotion of hydrolysis, a kinetic study was made using Z-Phe-Ala-Ala, Z-Ala-GlyGly-Leu, Z-Ala-Phe-Gly-Ala, and gelatin as substrates. From the Lineweaver-Burk plots (Fig. 1) their kinetic parameters were determined. The results are summarized in Table IV; they indicate that in each case the promotion relates mainly with binding $(\mathrm{Km})$ and only little with catalysis $\left(k_{\mathrm{cat}}\right)$.

Specificity against oxidized insulin $B$ chain in the presence of Co ion

We determined in a previous paper $^{7}$ the points of cleavage of oxidized insulin $B$ chain in the absence of Co ion. In the present work we have investigated whether these points of cleavage differ with the presence of Co ion in the reaction mixture. Digestion of $\mathrm{B}$ chain in the presence of Co ion was carried out according to the method described in MATERIALS AND METHODS. The peptides were separated by high voltage paper-electrophoresis, followed by paper-chromatography as shown in MATERIALS AND METHODS. The amino acid compositions of the respective peptides are shown in Table $\mathrm{V}$. The amino acid contents of II, IVA, and VIA were too small to be determined. From the known structure of the insulin molecule, it was possible to relate the composition of each peptide to a sequence of amino acids, as seen in the table. The points of cleavage in the $B$ chain 
Table IV. Kinetic Parameters of $P$. aeruginosa Alkaline Proteinase for Hydrolysis of Various Peptides and Gelatin in the Presence or Absence of Co Ion

The arrows show the bonds split.

\begin{tabular}{|c|c|c|c|c|}
\hline Substrates & $\begin{array}{c}{[\mathrm{Co}]} \\
(\mathrm{M})\end{array}$ & $\underset{(\mathrm{mM})}{K m}$ & $\begin{array}{c}k_{\mathrm{eat}} \\
\left(\sec ^{-1}\right)\end{array}$ & $\begin{array}{c}k_{\mathrm{cat}} / K m \\
\left(\mathrm{mM}^{-1} \cdot \sec ^{-1}\right)\end{array}$ \\
\hline \multirow{2}{*}{$\underset{\uparrow}{\text { Z-Phe-Ala-Ala }}$} & $10^{-2}$ & 0.4 & 0.62 & 1.55 \\
\hline & 0 & 1.7 & 0.30 & 0.18 \\
\hline \multirow{2}{*}{$\underset{\uparrow}{\text { Z-Ala-Gly-Gly-Leu }}$} & $10^{-2}$ & 5.4 & 6.8 & 1.26 \\
\hline & 0 & 25.0 & 5.0 & 0.2 \\
\hline \multirow{2}{*}{ Z-Ala-Phe-Gly-Ala } & $10^{-2}$ & 2.5 & 11.4 & 4.6 \\
\hline & 0 & 13.0 & 7.7 & 0.6 \\
\hline \multirow[t]{2}{*}{ Gelatin } & $10^{-2}$ & $0.94 \%$ & 182 & 194 \\
\hline & 0 & $4.4 \%$ & 89 & 20 \\
\hline
\end{tabular}

Table V. amino Acid Compositions of Peptides Obtained FRoM THE OXIDIZED INSUlin B Chain

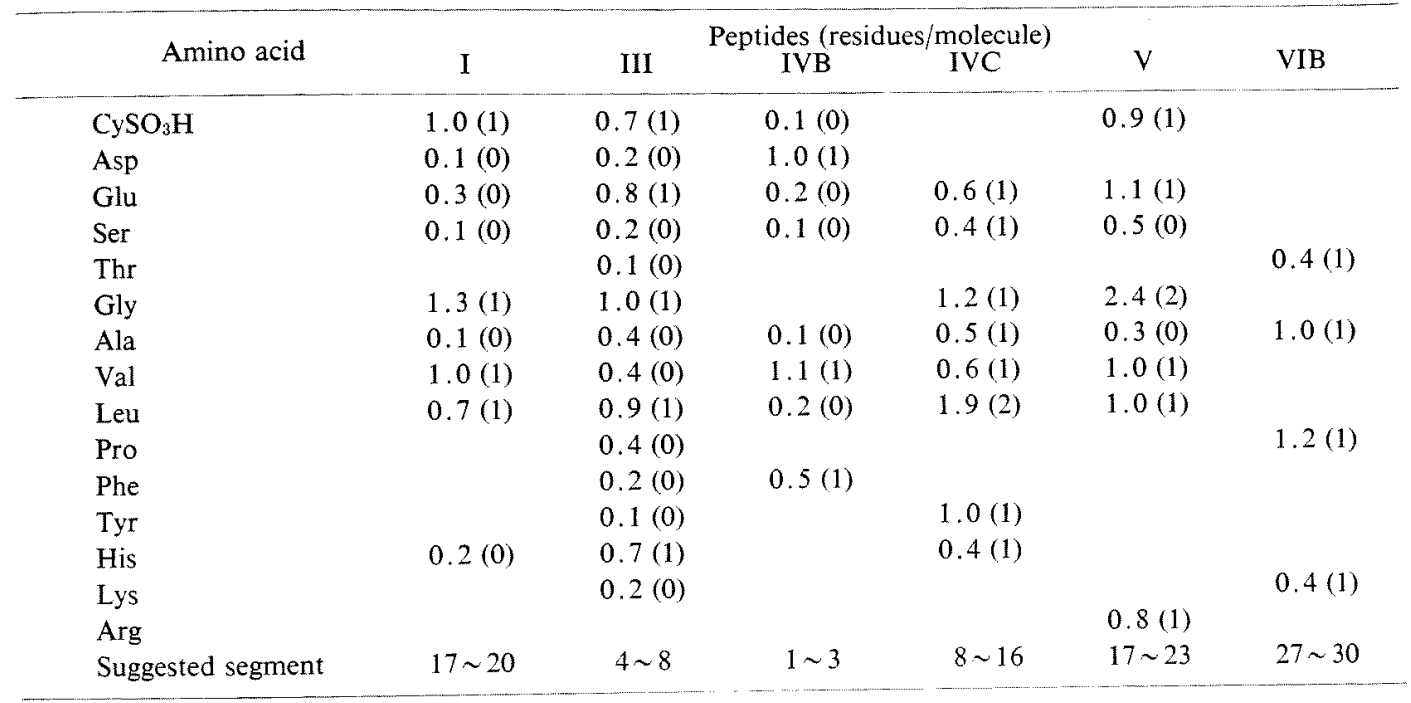

were thus deduced to be at Asn-Gln (3-4), $\mathrm{CySO}_{3} \mathrm{H}-\mathrm{Gly}(7-8)$, Gly-Ser (8-9), Tyr-Leu $(16-17)$, Gly-Glu (20-21), Gly-Phe (23-24), and Tyr-Thr (26-27). Hydrolysis of B chain by the alkaline proteinase in the absence of Co ion yielded the same points of cleavage, as shown in the previous paper. ${ }^{7}$ So it is shown that the specificity against the $B$ chain by the alkaline proteinase is identical not-withstanding the presence or absence of $\mathrm{Co}$ ion in the reaction mixture.

\section{DISCUSSION}

The present study indicated that the $P$. aeruginosa alkaline proteinase was inactivated by the addition of $o$-phenanthroline to the reaction mixture even in the presence of high concentration of $\mathrm{Ca}$ ion. This would indicate that the enzymatic activity is not related to $\mathrm{Ca}$ ion but to other heavy metal ions. Among various heavy metal ions tested, only Co ion was effective in promoting hydrolysis, and this was regardless of the kind of substrate, whether protein or synthetic peptide. For the maximum promotion of hydrolysis, a considerable concentration $\left(>5 \times 10^{-3} \mathrm{M}\right)$ was required, indicating that the $\mathrm{Co}$ ion binds loosely to the enzyme molecule. The kinetic study indicated that the promotion with Co ion related mainly 
with binding $(\mathrm{Km})$ and little with catalysis $\left(k_{\text {cat }}\right)$.

An alkaline proteinase produced by a strain belonging to Serratia has been found to be a Zn-enzyme, ${ }^{201}$ similarly as seen with metal neutral proteinases from bacterial origin. ${ }^{11,12}$ The specificity against oxidized insulin B chain is, however, considerably different ${ }^{211}$ from that of usual metal neutral proteinases but similar to that of the $P$. aeruginosa alkaline proteinase presented here. The apo-enzyme can easily be prepared by treatment with metal chelators, ${ }^{20}$ and it is easily reversed upon addition of approximately $1 \mathrm{mg}$ atom of $\mathrm{Zn}$, Co, or $\mathrm{Mn}$ per mole of enzyme. It is of great interest to note that the Co-substituted enzyme is about ten times as active against Hippuryl-L-leucineamide as the native or $\mathrm{Zn}$-enzyme, although the activities against casein are comparable with each other. It has also been found ${ }^{22}$ that the hydrolysis of synthetic peptides by clostridial collagenase is activated by $\mathrm{Co}$ ion to some extent.

It still remains to be solved whether the $P$. aeruginosa proteinase is a Co-enzyme in a real sense, although it is shown that the specificity against oxidized insulin $\mathbf{B}$ chain is identical in the presence or absence of $\mathrm{Co}$ ion in the reaction mixture.

\section{REFERENCES}

1) K. Morihara, J. Bacteriol, 88, 745 (1964).
2) K. Morihara, Biochim. Biophys. Acta, 73, 113 (1963).

3) H. Inoue, T. Nakagawa and K. Morihara, ibid., 73, 125 (1963).

4) K. Morihara and H. Tsuzuki, ibid., 92, 351 (1964).

5) K. Morihara, N. Yoshida and K. Kuriyama, ibid, 92, 361 (1964).

6) K. Morihara, H. Tsuzuki, T. Oka, H. Inoue and M. Ebata, J. Biol. Chem., 240, 3295 (1965).

7) K. Morihara and H. Tsuzuki, Arch. Biochem. Biophys, 114, 158 (1966).

8) K. Morihara, H. Tsuzuki and T. Oka, ibid, 123, 572 (1968).

9) K. Morihara and H. Tsuzuki, ibid, 120, 68 (1967),

10) K. Morihara, H. Tsuzuki and T. Oka, Biochim. Biophys. Acta, 309, 414 (1973).

11) J. D. McConn, D. Tsuru and K. T. Yasunobu, J. Biol. Chem., 239, 3706 (1964).

12) S. A. Latt, B. Holmquist and B. L. Vallee, Biochem. Biophys. Res. Commun., 37, 333 (1969).

13) K. Morihara, T. Oka and H. Tsuzuki, Arch. Biochem. Biophys., 135, 311 (1969).

14) H. Hayashi, Seikagaku, 32, 411 (1960).

15) F. Sanger, Biochem. J., 44, 126 (1949).

16) E. W. Yemm and E. C. Cocking, Analyst, 80, 209 (1955).

17) K. Morihara, T. Oka and H. Tsuzuki, Arch. Biochem. Biophys., 138, 515 (1970).

18) M. Ottesen and A. Spector, Compt. Rend. Trav. Lab. Carlsberg, 32, 63 (1960).

19) L. S. Sillen and A. E. Martel, "Stability Constants of Metal-Ion Complexes," The Chemical Society, Burlington House, London, 1964, p. 665.

20) K. Miyata, K. Tomoda and M. Isono, Agr. Biol. Chem., 35, 460 (1971).

21) K. Miyata, K. Tomoda and M. Isono, ibid, 34, 1457 (1970).

22) S. Yagisawa, F. Morita, Y. Nagai, H. Noda and Y. Ogura, J. Biochem., 58, 407 (1965). 